\title{
The Evolution of Public Health and Current Challenges: A Review
}

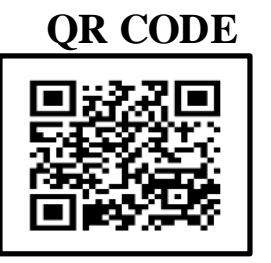

\section{DHRUV JOSHI ${ }^{* 1}$, MAYA SHARMA²}

From the ancient ages, the human has been plagued by numerous diseases. While ancient people attributed disease due to divine causation and was stigmatised or isolate from the society, the middle ages let scientists find a reasonable explanation for disease, which led to discoveries of microorganisms and maintaining a clean environment and thus, Public Health Was born. This review discusses the evolution of Public Health and current challenges faced by Public Health Professionals.

KEYWORDS: Public Health, Great Fire, Germ Theory, Cholera

\section{INTRODUCTION}

Public Health has a varied and diverse history, with disease being attributed to a divine causation, to discovering newer disease causing organisms and their subsequent treatment. This review paper discusses the evolution of Public Health Dentistry over the years.

\section{HISTORICAL BACKGROUND (PUBLIC HEALTH IN ANCIENT TIMES)}

In ancient times Greece, there were two rival Greek medical traditions; one was based on disease classification and the other on emphasizing the individual patient. Both were based on observation and not on divine causation. The Greek Physician Hippocrates also puts great emphasis on the environment in relation to health and well-being. ${ }^{1}$

The Romans and Chinese were known to have engineered safe water and sanitary latrines dating about 4000 years ago. A specialized military medical service was founded by the Romans who focused on the holistic well-being of the troops and also made connection between swamps and disease (specifically malaria), and determined salubrity was an important component of the selection of places of habitation for their troops. It is interesting to note that ancient terms describing disease are still in use, including the terms endemic and epidemic. Medieval practices related to ill-health was dominated by the church as it was believed that plagues were caused by divine retribution and certain illnesses were stigmatised. Toilets drained by covered severs were found in excavations of civilizations dating some 4000 years ago in the Indus valley. It has also been documented that around 2000 BC, cities including Troy, had highly developed water supply systems for its troops and residents. ${ }^{2}$

The disease leprosy during the ancient times was very common and sufferers were mostly stigmatised, forced into ghettos and were strictly made to comply with distinctive dress codes; they were supposed to sound a bell when people came near them. Throughout history, considerable attention has been directed to controlling transmissible diseases, improving the environment and providing safe drinking waters. ${ }^{1,2}$

As per Kiple (1993), The early modern transportation revolution in oceanic travel precipitated a new global order in the ecology of disease as by meeting far-flung people who never previously had any contact, started having major consequences of epidemic infections and hence, ushering a new wave of deadly diseases. 3 From the fifteenth century, the western world rose to global dominance, wealth, trade and military power. But as the west grew wealthier, it did not grow any healthier. The west's populations were, from time to time, decimated by pandemic Waves. ${ }^{3}$

\section{THE PERIOD OF ENLIGHTENMENT}

The years 1700 to 1799 are also known as the period of "The Enlightenment". The great figures during the Enlightenment strove to improve the world and the circumstances of humankind. Betterment of the public health was among the goals of many Enlightenment thinkers. It was an international intellectual movement that revolutionized political, 
philosophical, social, and scientific thinking. ${ }^{3}$

During the eighteenth century, the population of Prussia (Germany) increased dramatically. Berlin's population swelled five-fold during the years 1700 to 1797. Paris's population increased as well, but was a city with a reputation for unsanitary hospitals. People were concerned about the diseases of soldiers as well as the unhealthy conditions in institutions that housed the insane and criminals. 3

The concept of Medical Police (Germany, 1779) The most important European figure in the German public health movement was Johann Peter Frank (1745-1821), who established the concept of "medical police" with his publication of The System of Medical Police in 1779. The first known use of the term "medical police" was by German Wolfgang Thomas Rau (1668-1719). Frank's medical police dealt with problems of sanitation, such as sewage, garbage disposal, and maintaining clean water supplies. There was no more an important task than keeping cities and towns clean, said Frank, who arranged for public restrooms in cities and public dumping grounds far outside of cities and towns. ${ }^{3}$

In 1790, French physician Joseph Ignace Guillotine (1738-1814), for whom the guillotine was named, duly insisted that medical practice, medical education, "health police," sanitary services, and the control of diseases should be under the ambit of a "health committee", which led to a law being passed in 1793 that provided for the welfare and health of expectant mothers and children. In addition, the same convention decreed that every hospital patient should have his own bed and that the beds should be separated by 3 feet $(7.6 \mathrm{~cm})$. The noted French physician Philippe Pinel (1745-1826) similarly improved the treatment of the incarcerated insane by removing their chains and demonstrating that more humane treatment of the mentally ill had a greater social value.

Erstwhile, the population of London swelled quickly in the eighteenth century. Jonathan Swift wrote "A Modest Proposal", an essay satirically proposing that the answer to the increasing population was to eat babies. New hospitals and medical "dispensaries" opened in many parts of England, including York, Bristol, and estminster; previously, most had been only in London. The great Englishman, John Howard published the book titled "State of the Prisons", which outlined his investigations of unsanitary British jails. Ultimately reformed the appallingly unsanitary conditions he found in prisons in England and Europe.

\section{IMPORTANT ACHIEVEMENTS}

James Lind (1716-1794): Helped reduce scurvy among British seamen by encouraging them to use lime juice

Robert Willan: Described the various skin ailments of workers and connected them to work-related health risks.

William Tuke: Was a tea and coffee merchant, reformed the British asylums by creating a "retreat" in York, England, that housed 30 mental patients and treated them more humanely than they were treated in the asylums, and with good results

Edward Jenner (1749-1823): 1790- Noticed that milkmaids did not get smallpox, a disease ravaging the world. They did, however, get cow pox from the cows they milked, leading Jenner to think their exposure to cowpox protected them from smallpox. He began inoculating people with cowpox in attempt to save them from smallpox. His efforts lead to "vaccinations" which eventually eliminated many diseases, including smallpox

\section{THE GREAT FIRE OF LONDON 4,5}

The Great Fire of London was a major conflagration that swept through the central parts of the English city of London, from Sunday, and September to Wednesday, 5th September 1666. The fire gutted the medieval City of London inside the old Roman City Wall. Such was the impact of the fire that it was estimated to have destroyed the homes of 70,00o of the City's total of 8o,0oo inhabitants. The Great Fire started at the bakery of Thomas Farriner (or Farynor) on Pudding Lane in London.

\section{Public Health Importance}

The Great Fire led to destruction of 84 churches and the old St Paul's Church. In contrast, all was not lost as it also destroyed the filthy streets associated the Great Plague as the Fleet, a 'tributary' that flowed into the Thames, was nothing more than an open sewer associated with disease and poverty. The fire, whih lasted for approximately 3 days boiled the Fleet and sterilised it. Slums were simply burned away and the fire did London a favour and it was now up to the city's authority's to re-build and re-plan the city. Fire 
fighting systems of the country were also revamped as they had failed to contain the fire and most of the fire dousing had to be done by the locals themselves.

\section{THE GREAT SANITARY AWAKENING 6-9}

The beginning of the modern concern for community drinking water quality began about 150 years ago in both Britain and the United States. (1842). New York City, in response to a prevalent epidemic of waterborne cholera that took the lives of more than 3,500 people, sought a new water supply for its residents. The summer of 1842 in London was "marked by perhaps a greater incidence of unemployment, destitution, and social protest than any other in the 19th century"

\section{MIASMA THEORY OF DISEASE3}

Began in the middle ages an continued till the mid 180o's and was used to explain the spread of cholera in London and Paris. The theory held that diseases such as cholera or black death were caused by miasma(Greek-pollution) considered to be a poisonous vapour or mist that is filled with particles of decomposed matter(miasmata) that could cause illness. The miasmata was identifiable by its Nasty, Foul smell, which came from decomposed material.

\section{BRITISH PUBLIC HEALTH MOVEMENT ${ }^{9}$}

The movement was initiated by findings of Dr. John Snow (1854) who proposed that microorganisms are the causes of many diseases through his statistical analysis of the 1854 cholera outbreak in Soho, a British Neighbourhood which revealed drinking water as vessel for disease transmission as the cases were only those who obtained water from broad Street pump (outbreak centre) and Hence, the year 1880 was the start of the "Modern Era Of Public Health".

\section{PUBLIC HEALTH APPROACHES TO HEALTH PROBLEMS ${ }^{1,11}$}

- Surveillance: What is the problem?

- Risk Factor Identification: What is the cause?

- Intervention Evaluation: What works?

- Implementation: How do you do it?

\section{CRITERIA FOR A PUBLIC HEALTH PROBLEM $^{12}$}

- Prevalence of the condition
- Impact of the condition on an individual level

- Condition is preventable and effective treatments are available

- Impact on wider society

\section{ACHIEVEMENTS OF PUBLIC HEALTH IN} THE $20^{\text {th }}$ CENTURY: CDC ${ }^{13}$

- Access to safe water and sanitation

- Increased awareness and Response for Improving Global Road Safety

- Vaccine-Preventable Diseases

- Improved Preparedness and Response to Global Health Threats

- Malaria prevention and control

- Reductions in child mortality

- Tobacco Control

- Prevention and Control of HIV/AIDS

- Control of Neglected Tropical Diseases

- Tuberculosis Control

\section{MAJOR PUBLIC HEALTH THREATS ${ }^{14,15}$}

- Potential threat of biological, chemical, and radiological terrorism

- Environmental threats.

- Infectious diseases - West Nile virus and Norovirus outbreaks, mad cow disease, foodborne pathogens, Asian flu pandemic, flu vaccine shortage, decreased rate of immunizations (20 percent of pre-schoolers do not receive all recommended Vaccinations). Ebola virus and Zika Virus.

- Substance abuse and obesity across the globe.

- HIV epidemic amongst gay men (August 2011)

- Growing prevalence of cancer, heart disease, diabetes, asthma, and other chronic diseases across all age groups.

- Increasing public violence.

\section{MAJOR PUBLIC HEALTH THREATS- ENVIRONMENTAL}

- Tsunamis, floods and other environmental disasters

- Global Warming

- Terrorism(bioterrorism)

- Anthrax

- Nuclear radiation leakage

- Political unrest and turmoil 


\section{REFERENCES}

1. Hemingway A. The Historical Origins of Public Health. Bournemouth University(2002)

2. Rosen G. A History of Public Health. New York. NY: MD Publications; 1958

3. Filmore R. Developments in Public Health: An entry from Gale's Science and Its Times(2000).132-134

4. Hanson N. (2002). The Great Fire of London: In That Apocalyptic Year, 1666. Hoboken, New Jersey: John Wiley and Sons.

5. Leasor J (1961, 2011). The Plague and the Fire. WorldpressInstitute of Medicine (1988). The Future of Public Health. Washington, D.C.: National Academy Press.

6. The Story of a Laboratory, Chapter One: The Sanitary Awakening. Department of Health Laboratory of Greenwich, Connecticut (USA) .o

7. http://laboratorystories.blogspot.in/p/the-storyof-laboratory-chapter-one_2o.html.[Last Accessed on 15 August, 2018]

8. Shattuck, L. (1850). Rep. of the Sanitary Commission of Massachusetts. Harvard Univ. Press, Cambridge, Mass

Source of support: Nil, Conflict of interest: None declared
9. Snow J. (1936). "Snow on cholera." Oxford Univ. Press, London, England.

10. U.S. Public Health Service, For a Healthy Nation: Returns on investment in Public Health (Washington, D.C., U. S. Government Printing Office,1994.

11. CDC Injury Fact Book, 2006. (http://www.cdc.gov/ncipc/fact_book/factbo ok.htm)[Last Accessed on 2oth August, 2018]

12. Daly B, Watt R, Batchelor P, Treasure E. Essential Dental Public Health;2002

13. Centers for Disease Control and Prevention. Ten Great Public Health Achievements Worldwide, 2001-2010. MMWR 2011;60:814818

14. www.healthyamericans.org [Last Accessed $12^{\text {th }}$ June, 2018]

15. Okrent D, Polan S, Deanna. Public Healthchapter 12.Alliance for Health Reform, (2012). E-chapter http://www.allhealth.org/sourcebookcontent. asp?CHID =128j [Last Accessed on 15th August, 2018]
Cite this article as:

Joshi D, Sharma M. The Evolution of Public Health and Current Challenges: A Review Int Healthc Res J 2018;2(8):184-187. doi: 10.26440/ihrj.v2i8.166

\section{$\frac{\text { AUTHOR AFFILIATIONS: }}{\text { MDS, Private }}$ \\ 1. MDS, Private Practitioner and Dental Consultant \\ 2. BDS, Consultant Dental Surgeon}

